\title{
Effectiveness of successful application of herbicides 'Chemical Glyphosate' and 'Himstop' 330 against annual and perennial weeds in cotton fields of Uzbekistan
}

\author{
Makhkam Shodmanov ${ }^{1, *}$ and Ozoda Mustafoeva ${ }^{1}$ \\ ${ }^{1}$ Tashkent State Agrarian University, University str., 2, Tashkent province, Uzbekistan, 100140
}

\begin{abstract}
This article provides information on the effectiveness of successive application of herbicides chemical glyphosate (CG) (3 l/ha) and Himstop $330(1.5 \mathrm{l} / \mathrm{ha})$ against annual and perennial weeds in cotton fields. When Himstop 330 was used at a rate of $1.51 / \mathrm{ha}$, the number of annual weeds was reduced by $84.6-90.4 \%$. $14.5-17.9 \%$. When CG $54 \%$ herbicide was applied at a rate of $3.0 \mathrm{l} / \mathrm{ha}$, annuals were reduced by $16.5-19.4 \%$, while perennials were reduced by $86.4-91.5 \%$.CG, when applied in the fall at a rate of $3.01 / \mathrm{ha}$, and Himstop 330, at a rate of $1.5 \mathrm{l} / \mathrm{ha}$ (in series) with the sowing of annual weeds $89.6-94.5 \%$, perennials 88.2 - Provides a loss of $92.6 \%$. When CG was used separately at a rate of $3.0 \mathrm{l} / \mathrm{ha}$ and Himstop 330 at a rate of $1.51 / \mathrm{ha}, 3.25 \mathrm{q} / \mathrm{ha}$ more cotton was obtained than the control variant. CG (3.0 l/ha) and Himstop 330 (1.5 1/ha) herbicides when applied in series provide a high cotton yield of $5.2 \mathrm{q} / \mathrm{ha}$ per hectare.
\end{abstract}

\section{Introduction}

It is known that perennials such as Bermuda grass (Cynadon dactylon L.), Aleppo grass (Sorgum halepense L. Brot), field bindweed (Convolvulus arvensis L.), purple nutsedge (Cyperus rotundus L.), goosefoot (Cyhenopodium album L.), and annual weeds such as beauv (Echinochloa crus-galli L.), black nightshade (Solanum nigrum L.), purslane (Portulaca oleraceae L.) and redroot pigweed (Amarathus retraflexus) are common. In areas strongly and moderately infested with these weeds, the growth and development of agricultural crops lags behind, and the yield and quality of yields decline sharply $[1,2,8]$.

If cotton, carrots, onions, and many other crops remain in the grass at the beginning of the growing season, the damage from weeds will be enormous, resulting in the negative effects of weeds on the later phases of the growing season. [4, 6-8].

Weeds belonging to different families will be adapted to grow under certain environmental conditions. For example, weeds such as tulips, asterisks, wild oats, and ostrichs grow in wheat fields, while weeds such as Bermuda grass, wild rose hips, purslane, black nightshade, goosefoot, Aleppo grass, field bindweed, beauv, purple nutsedge grow

${ }^{*}$ Corresponding author: makhkam.shodmanov@yandex.com 
among cotton. The use of wheat-cotton crop rotation allows to reduce these weeds by drastically changing the growing conditions $[3,8,11]$

A single herbicide has different effects on different weeds. Therefore, chronic application of one herbicide leads to an increase in the number of weeds that are resistant to these herbicides. In experiments conducted at UzPITI [1], the use of kotoran for four years in the phytocenosis of weeds reached $78 \%$, and when using promethrin - $48 \%$. Similar patterns have been observed in other regions. For example, the chronic use of simazine herbicide in maize fields increased the number of weed-resistant weeds from year to year. [8].

Other scientists have noted that the effects of chronic herbicides on weeds are declining from year to year. This negative process can be stopped by alternating application of herbicides with different areas of action, the use of mixtures, sequential application. Because drugs that kill annual weeds well have a weak effect on perennials, herbicides that effectively kill perennials have a weak effect on perennials [5, 9]. Based on this, we conducted experiments to determine the effectiveness of sequential application of Uzbekproduced herbicides "Chemical Glyphosate" (CG - analogue of Raundap herbicide) and Himstop 330 (analogue of Stomp's herbicide) against annual and perennial weeds in cotton fields. Clearing the fields of weeds by increasing the effectiveness of chemical control measures will increase the quantity and quality of the cotton crop $[4,10]$.

The aim of the research is to develop methods to increase the effectiveness of chemical control measures against consecutive application of annual and perennial herbicides CG and Himstop against typical gray soils of Tashkent province.

\section{Materials and Methods}

Scientific research was carried out in 2019-2020 in the conditions of typical gray soils of Tashkent province. Designed methods were used in conducting and conducting the experiment $[5,10]$. The experiment was performed in 4 repetitions of 4 variants (Table 1 ). S-6524 variety of cotton was planted.

Table 1. Scheme of the experiment

\begin{tabular}{|c|c|c|}
\hline$\#$ & Options & Herbicide, $\mathbf{l} / \mathbf{h a}$ \\
\hline 1 & Control (without herbicide) & - \\
\hline 2 & Himstop $330,33 \%$ & 1.5 \\
\hline 3 & CG, $54 \%$ & 3.0 \\
\hline 4 & CG+Himstop & $3.0+1.5$ \\
\hline
\end{tabular}

The soils of the experimental area are moderately sandy, typical gray soils in terms of mechanical composition. Groundwaters are located at a depth of $4 \mathrm{~m}$.

In the selection and preparation of land for the experiment, the typicality of the soil, the degree of supply of humus and nutrients were studied. Amir Gayrat farm in Boka district of Tashkent province was selected for the study. The options were placed in a single tier. Egat length is $40 \mathrm{~m}$. Each option is 8 . row, i.e. at the expense of one visit of the drill $(8 \times 90 \mathrm{~cm}=$ 7.2 meters, $7.2 \times 40$ meters $=288 \mathrm{~m}^{2}$ ). The total area of one plots is $288 \mathrm{~m}^{2}$, the calculated area is $144 \mathrm{~m}^{2}$. Therefore, the total area of the experiment is $1,120 \mathrm{~m}^{2}$, and the calculated area is $560 \mathrm{~m}^{2}$. 
CCG is a $54 \%$ aqueous solution produced by Chimreaktivtaminot LLC in Uzbekistan. The active ingredient is glyphosate. In late September, perennial weeds growing in early October were sprayed en masse against unfinished perennial and annual weeds.

Himstop 330 - manufactured in Uzbekistan by "Khimreaktivtaminot" LLC. The herbicide has the ability to selectively act internally (systemically). It acts on annual onestage and two-stage weeds by rooting.

The following phenological observations were made in the experiment: - the date of sowing of cotton, the beginning of germination of seedlings, the time of germination; combing, flowering, fruiting and opening of pods. The days that elapsed from weeding to full ripening; - 1000 seed weight was determined; In determining the yield of cotton, each plots was harvested from the field. Calculation of the thickness of cotton seedlings was carried out 2 times during the growing season.

- After the first time the cotton is completely single (at the end of May)

- The second time at the end of the growing season, during the cotton harvest

In the experiment, 4 points were selected from 4 plots to determine the thickness of cotton seedlings (length of 1 point was $11.1 \mathrm{~m}$ ).

\section{field:}

The following agrochemical properties of soil are studied in the experimental

- To determine the agrochemical parameters of the soil of the experimental field, mixed soil samples were taken from 5 points of the field in the spring in the form of envelopes from $0-30$ and $30-50 \mathrm{~cm}$ soil layers. The total humus in these samples, the amount of humus I.M.Tyurin; nitrogen and phosphorus I.M. Maltseva, L.N. Gritsenko; nitrate nitrogen-ionometric instrument; mobile phosphorus was determined by B.P. Machigin and exchangeable potassium P.V.Protasov methods [3].

- Samples were taken in the laboratory to determine the amount of NPK, general and mobile forms, humus humus in the layer of $0-30 \mathrm{~cm}$ and $30-50 \mathrm{~cm}$ before planting on the drive, sub-driving layers of soil.

- The bulk density of the soil was determined in layers of 0-10, 10-20, 20-30 and 30-50 cm every 0-100 cm depth.

\section{Results and discussion}

In the experimental fields, annual weeds are found mainly "Bermuda grass", wild "redroot pigweed", "goosefoot", "black nightshade", "purslane", perennials "field bindweed" and "beauv".

The number of weeds was taken into account before cultivation after each watering. In the herbicide-free control variant, 39.2 annuals and 4.75 perennial weeds were recorded per 1 $\mathrm{m}^{2}$ of land during the $1 \mathrm{st}$ accounting period (Table 2). In the calculation period obtained before cultivation after the first irrigation, the "plot" was 16.4 units $/ \mathrm{m}^{2}$ in the control option. "Goosefoot" - 7.5 pieces per $1 \mathrm{~m}^{2}$, "wild rose" - 5.75 pieces, "black nightshade" 4.25 pieces, "purslane" -5.25 pieces.

When Himstop was sprayed at a rate of $1.51 /$ ha, the amount of "build" was 1.50 pieces. In this variant, the number of annual weeds was 3.75 pieces $/ \mathrm{m}^{2}$. CCG had a weak effect on annual weeds when applied separately at a rate of $54 \%$ to $3.0 \mathrm{l} / \mathrm{ha}$. In this variant the presence of 12.7 pieces $/ \mathrm{m}^{2}$, "goosefoot" - 6.25, wild "redroot pigweed" - 4.75, "black nightshade" - 3.35, "purslane" - 4.50 and in total 31.6 pieces $/ \mathrm{m}^{2}$ and annual weeds taken into account.

Similar data were obtained during the second accounting period. Himstop $3301.5 \mathrm{l} / \mathrm{ha}$ in the norm sown variant "Bermuda grass " -1.5 pieces $/ \mathrm{m}^{2}$, "goosefoot" -1.0 pieces $/ \mathrm{m}^{2}$, 
wild "redroot pigweed" - 0.8 pieces $/ \mathrm{m}^{2}$, "black nightshade" - 0.75 pieces $/ \mathrm{m}^{2}$, and "purslane" - 0.75 pieces $/ \mathrm{m}^{2}$.

Table 2. Effects of herbicides on weed species

\begin{tabular}{|c|c|c|c|c|c|c|c|c|c|c|}
\hline \multirow[b]{2}{*}{$\#$} & \multirow[b]{2}{*}{ Options } & \multicolumn{6}{|c|}{ Annual weeds, $\mathrm{pcs} / \mathrm{m}^{2}$} & \multicolumn{3}{|c|}{$\begin{array}{c}\text { Perennial weeds, } \\
\text { pcs } / \mathrm{m}^{2}\end{array}$} \\
\hline & & 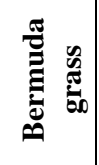 & 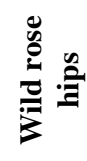 & 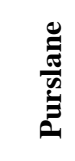 & 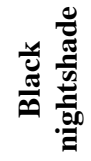 & $\begin{array}{l}\overrightarrow{8} \\
\dot{0} \\
\dot{0} \\
\dot{0} \\
\dot{0}\end{array}$ & 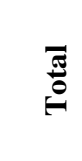 & 旁势 & 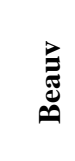 & 焉 \\
\hline \multicolumn{11}{|c|}{ First observation } \\
\hline 1 & $\begin{array}{c}\text { Control } \\
\text { (without } \\
\text { herbicide) }\end{array}$ & 16.4 & 7.50 & 5.75 & 4.25 & 5.25 & 39.2 & 2.25 & 2.50 & 4.75 \\
\hline 2 & $\begin{array}{c}\text { Himstop } 330 \\
1.5 \mathrm{l} / \mathrm{ha}\end{array}$ & 1.50 & 0.75 & 0.50 & 0.45 & 0.50 & 3.75 & 2.00 & 2.00 & 4.00 \\
\hline 3 & $\begin{array}{c}\text { CG, } 54 \% 3.0 \\
1 / \mathrm{ha}\end{array}$ & 12.7 & 6.25 & 4.75 & 3.35 & 4.50 & 31.6 & 0.25 & 0.20 & 0.45 \\
\hline 4 & $\begin{array}{c}\text { CG } 3.0 \text { 1/ha }+ \\
\text { Himstop } 1.5 \\
\text { 1/ha } \\
\end{array}$ & 1.25 & 0.25 & 0.25 & 0.20 & 0.25 & 2.00 & 0.15 & 0.20 & 0.35 \\
\hline \multicolumn{11}{|c|}{ Second observation } \\
\hline 1 & $\begin{array}{c}\text { Control } \\
\text { (without } \\
\text { herbicide) }\end{array}$ & 12.5 & 5.25 & 4.75 & 3.50 & 4.75 & 30.8 & 2.50 & 3.00 & 5.50 \\
\hline 2 & $\begin{array}{c}\text { Himstop } 330 \\
1.5 \mathrm{l} / \mathrm{ha} \\
\end{array}$ & 1.50 & 1.00 & 0.80 & 0.75 & 0.70 & 4.75 & 2.30 & 2.50 & 4.80 \\
\hline 3 & $\begin{array}{c}\text { CG, } 54 \% 3.0 \\
1 / \mathrm{ha}\end{array}$ & 10.5 & 5.50 & 3.50 & 2.70 & 3.50 & 25.7 & 0.35 & 0.40 & 0.75 \\
\hline 4 & $\begin{array}{c}\text { CG } 3.0 \text { 1/ha }+ \\
\text { Himstop } 1.5 \\
\text { 1/ha }\end{array}$ & 1.35 & 0.70 & 0.50 & 0.35 & 0.30 & 3.20 & 0.30 & 0.35 & 0.65 \\
\hline
\end{tabular}

CCG had a weak effect on annual weeds when applied separately at a rate of $54 \%$ to 3.0 $1 /$ ha. In this variant, "Bermuda grass “ is 10.5 pieces $/ \mathrm{m}^{2}$, "goosefoot" - 5.50 pieces $/ \mathrm{m}^{2}$, wild "redroot pigweed" - 3.50 pieces $/ \mathrm{m}^{2}$, "black nightshade" - 2.70 pieces $/ \mathrm{m}^{2}$, "purslane" - 3.50 pieces $/ \mathrm{m}^{2}$ and a total of 25.7 pieces $/ \mathrm{m}^{2}$ per year the presence of weeds is taken into account.

Himstop 330 only affected perennial weeds that came from seed. In the control variant, "field bindweed" was 2.25 pieces $/ \mathrm{m}^{2}$ and "beauv" was 2.50 pieces $/ \mathrm{m}^{2}$. In the variant where the herbicide Himstop 330 was applied at a rate of $1.51 /$ ha, the "field bindweed" was 2.30 pieces $/ \mathrm{m}^{2}$, and the "beauv" was 2.50 pieces $/ \mathrm{m}^{2}$ for a total of 4.80 pieces $/ \mathrm{m}^{2}$. When CG $54 \%$ applied with the rate of $3.0 \mathrm{l} / \mathrm{ha}$, there were contained $0.35 \mathrm{pieces} / \mathrm{m}^{2}$ of "goosefoot", 0.40 pieces $/ \mathrm{m}^{2}$ of "peat", and a total of 0.75 pieces $/ \mathrm{m}^{2}$ of perennial weeds.

When consecutive use of CG (3 1/ha) and Himstop (1.5 1/ha), the number of single-stage and two-stage annual weeds was effectively reduced compared to the variants in which these pesticides were used separately. The number of "Bermuda grass " in this variant averaged 1.25 pieces $/ \mathrm{m}^{2}$, goosefoot 0.25 pieces, wild "redroot pigweed" - 0.25 , "black nightshade" and "purslane" $0.20-0.25$ pieces.

The total number of annual weeds was 2.0. Himstop 330 herbicide partially affected the emergence of perennial weed seeds. The efficacy of herbicides against weeds is given in 
Table 3. When using Himstop 330 at a dose of 1.5 1/ha, 84.6-90.4. When the herbicide CG was applied at a rate of $3.01 /$ ha, annuals were reduced by $16.5-19.4 \%$, while perennials were reduced by $86.4-91.5 \%$.

When Himstop 330 was applied at a rate of $1.51 /$ ha, the dry mass of annual weeds was reduced by $85.5-90.2 \%$. In this variant, the dry mass of perennial weeds decreased by $13.2-$ $15.5 \%$. When Himstop 330 was used at a rate of $2.01 /$ ha, the dry mass of annual weeds decreased by $88.3-92.5 \%$, while the mass of perennial weeds decreased by $15.7-18.7 \%$. When CG 54\% applied at a rate of $3.01 /$ ha, the dry mass of annual weeds decreased by $17.5-21.7 \%$, the dry mass of perennial weeds decreased by $87.0-90.5 \%$. When CG $3.01 /$ ha and Himstop 330 were used consecutively at $1.51 /$ ha, the dry mass of annuals decreased by $90.2-94.2 \%$ and the dry mass of perennials by $90.4-92.0 \%$.

This means that in order to effectively reduce the number and dry mass of annual and perennial weeds in the cotton field, it is necessary to apply CG 3.0 1/ha and Himstop 330 $1.51 /$ ha consecutively.

Table 3. Reduction of weeds under the influence of herbicides

\begin{tabular}{|c|c|c|c|c|c|c|c|c|c|}
\hline \multirow{3}{*}{$\#$} & \multirow{3}{*}{ Options } & \multicolumn{4}{|c|}{ Annual weeds } & \multicolumn{4}{|c|}{ Perennial weeds } \\
\hline & & \multicolumn{2}{|c|}{ First observation } & \multicolumn{2}{|c|}{ Second observation } & \multicolumn{2}{|c|}{ First observation } & \multicolumn{2}{|c|}{ Second observation } \\
\hline & & $\mathrm{pcs} / \mathrm{m}^{2}$ & $\begin{array}{c}\text { reduction, } \\
\%\end{array}$ & $\mathrm{pcs} / \mathrm{m}^{2}$ & $\begin{array}{c}\text { reduction, } \\
\%\end{array}$ & $\mathrm{pcs} / \mathrm{m}^{2}$ & $\begin{array}{c}\text { reduction, } \\
\%\end{array}$ & $\mathbf{p c s} / \mathrm{m}^{2}$ & $\begin{array}{c}\text { reduction, } \\
\%\end{array}$ \\
\hline 1 & $\begin{array}{c}\text { Control } \\
\text { (without } \\
\text { herbicide) }\end{array}$ & 39.2 & - & 30.8 & - & 4.75 & - & 5.50 & - \\
\hline 2 & $\begin{array}{c}\text { Himstop } \\
3301.5 \\
1 / \mathrm{ha} \\
\end{array}$ & 3.75 & 90.4 & 4.75 & 84.6 & 4.00 & 15.8 & 4.80 & 12.5 \\
\hline 3 & $\begin{array}{c}\text { CG 54\% } \\
3.01 / \mathrm{ha} \\
\end{array}$ & 31.6 & 19.4 & 25.7 & 16.5 & 0.40 & 91.5 & 0.75 & 86.4 \\
\hline 4 & $\begin{array}{c}\text { CG 3.0 1/ha } \\
+ \text { Himstop } \\
1.51 / \mathrm{ha}\end{array}$ & 2.00 & 94.5 & 3.20 & 89.6 & 0.35 & 92.6 & 0.65 & 88.2 \\
\hline
\end{tabular}

In agriculture, all agro-technical measures are aimed at creating favorable conditions for the growth and development of crops. Timely eradication of weeds plays an important role in these measures. Fields heavily contaminated with weeds cannot be cleared of weeds in a short period of time. This causes the growth and development of the cotton at the beginning of the growing season to be delayed. Keeping the fields clean from the beginning of the growing season can only be achieved with the help of herbicides. As can be seen from Table 4 , in the variants in which herbicides were used, the height of the cotton and the number of live leaves were significantly higher than in the control variant.

Table 4. Height and number of matured leaves of cotton

\begin{tabular}{|c|c|c|c|c|c|}
\hline \multirow{2}{*}{$\#$} & \multirow{2}{*}{$\begin{array}{c}\text { Matured } \\
\text { leaves, pcs }\end{array}$} & \multicolumn{4}{|c|}{ Height of plant, cm } \\
\cline { 3 - 6 } & June 1 & July 1 & August 1 & September 1 \\
\hline 1 & 6.15 & 21.1 & 58.5 & 87.4 & 89.0 \\
\hline 2 & 6.35 & 24.5 & 63.4 & 93.0 & 95.4 \\
\hline 3 & 6.15 & 23.2 & 61.2 & 92.4 & 94.4 \\
\hline 4 & 6.35 & 23.5 & 64.2 & 95.5 & 97.5 \\
\hline
\end{tabular}


On June 1, the height of cotton was $21.1 \mathrm{~cm}$ in the control variant, and in the variant where the samurai herbicide was used at a rate of $1.5 \mathrm{l} / \mathrm{ha}$, the height of the cotton was 24.5 $\mathrm{cm}$. CG 54\% 3.0 1/ha In the variant used in moderation, the height of the cotton was 23.2 $\mathrm{cm}$.

This difference was even greater in the variant when used in series with CG, with Himstop $(2.4 \mathrm{~cm})$. In this variant (September 1), the height of the cotton was $97.5 \mathrm{~cm}$. During this period, the height of the cotton was $89.0 \mathrm{~cm}$ in the control variant

The number of harvest branches was also lower in the control variant than in the experimental variant and was 14.2 (Table 5). In the experimental variants, this figure averaged 15.2-16.0 units per plant. Yield elements were also higher in the variants where herbicides were used than in the control variant.

Table 5. Number of crop branches and elements of cotton in the field where herbicides were applied, pcs/plant

\begin{tabular}{|c|c|c|c|c|c|c|c|}
\hline \multirow{2}{*}{$\#$} & \multicolumn{3}{|c|}{ Harvestable branches, pcs } & \multicolumn{2}{c|}{ August 1 } & \multicolumn{2}{c|}{ September 1 } \\
\cline { 2 - 8 } & July 1 & August 1 & September 1 & $\begin{array}{c}\text { Early } \\
\text { cocoon }\end{array}$ & $\begin{array}{c}\text { Mid } \\
\text { cocoon }\end{array}$ & $\begin{array}{c}\text { Mid } \\
\text { cocoon }\end{array}$ & $\begin{array}{c}\text { Mature } \\
\text { cocoon }\end{array}$ \\
\hline 1 & 7.50 & 13.4 & 14.2 & 2.20 & 3.70 & 7.25 & 0.50 \\
\hline 2 & 8.75 & 15.2 & 15.2 & 2.10 & 3.12 & 8.50 & 1.50 \\
\hline 3 & 8.25 & 14.6 & 15.5 & 2.60 & 3.35 & 8.00 & 1.25 \\
\hline 4 & 9.00 & 15.8 & 16.0 & 3.50 & 4.25 & 9.00 & 2.00 \\
\hline
\end{tabular}

In the variants CG and Himstop herbicides used separately, the cocoons were 1.0-0.75 more than in the control. In the variant where the herbicides CG and Himstop were applied in series, the number of pods was 1.50 more than in the control variant.

Consecutive application of herbicides with different areas of exposure ensures that the fields are free of weeds in a timely manner, creates favorable conditions for cotton growth and development, and ensures that the cotton yield is higher than the herbicide-free option.

Sequential application of herbicides with different areas of exposure ensures that the fields are free of weeds in a timely manner, creates favorable conditions for cotton growth and development, and ensures that the cotton yield is higher than the herbicide-free option.

Table 6. Cotton yield, q/ha

\begin{tabular}{|c|c|c|c|c|c|c|}
\hline \multirow{2}{*}{$\#$} & Options & \multicolumn{3}{|c|}{ Harvest, q/ha } & \multirow{2}{*}{ Total } & $\begin{array}{c}\text { Difference } \\
\text { from control }\end{array}$ \\
\cline { 3 - 5 } & Control & 17.5 & 5.20 & 2.60 & 25.3 & - \\
\hline 2 & Himstop 330, 1.5 1/ha & 20.0 & 5.60 & 3.0 & 28.6 & 3.25 \\
\hline 3 & CG, 54\% 3.0 1/ha & 19.5 & 5.40 & 3.70 & 28.6 & 3.25 \\
\hline 4 & $\begin{array}{c}\text { CG 3.0 1/ha } \\
+ \text { Himstop, 1.5 1/ha }\end{array}$ & 21.4 & 5.80 & 3.70 & 30.5 & 5.20 \\
\hline
\end{tabular}

$\mathrm{HCP}_{05}-1.4 \mathrm{q} / \mathrm{ha} ; \mathrm{HCP}_{05}-4.80 \%$

In the control variant, the cotton yield was $25.3 \mathrm{q} / \mathrm{ha}$. Himstop 330 herbicide at a rate of $1.5 \mathrm{l} / \mathrm{ha}$, and CG 54\% in the fall applied at a rate of $3.0 \mathrm{l} / \mathrm{ha}$, yielded 3.25 times more cotton 
than the control option. When Himstop 330 herbicides were used in series with $\mathrm{CG}$, a higher cotton yield was obtained at $5.2 \mathrm{q} /$ ha compared to the control option.

\section{Conclusion}

In order to effectively eradicate weeds with different biological properties, it is necessary to apply herbicides with different exposures alternately or sequentially. The number of annual weeds decreased by $84.6-90.4 \%$ when Himstop 330 was used at a dose of $1.5 \mathrm{l} / \mathrm{ha}$. In this variant, the herbicide perennial weeds were weakly affected, ie the effectiveness was only 12.5 , respectively. $-15.8 \%$ and $14.5-17.9 \%$, respectively. CG $54 \%$ herbicide applied at a rate of $3.01 /$ ha reduced annual weeds by $16.5-19.4 \%$, this reduced perennials by $86.4-91.5 \%$. CG $3.0 \mathrm{l} /$ ha in autumn and Himstop 330, $1.5 \mathrm{l} /$ ha in combination with seed sowing (in series) $89.6-94.5 \%$ of annual weeds, $88 \%$ of perennials, provides a loss of 2-92.6\%. When CG 3.0 1/ha and Himstop 3301.5 1/ha were used separately, 3.25 $\mathrm{q} /$ ha more cotton was obtained than the control variant. The herbicides CG $(3.0 \mathrm{l} / \mathrm{ha})$ and Himstop $330(1.5 \mathrm{l} / \mathrm{ha})$ provide a high cotton yield of $5.2 \mathrm{q} / \mathrm{ha}$ per hectare when applied in series.

\section{References}

1. B. G. Aleev, Agricultural Sciences 25, 7-21 (2005)

2. B. G. Aleev, T. Nasirova, L. G. Plakhova, Agricultural Brochure, 47-59 (1999)

3. M. A. Belousov, Methods of agrochemical, agrophysical and microbiological research in irrigated cotton areas (Tashkent, 1993)

4. B. A. Dospekhov, Field experiment technique (Kolos, Moscow, 2015)

5. I. I. Liberstein, Herbicides on field crops in Moldova (Stennica, Kishinev, 2013)

6. SH. Nurmatov, Methods of conducting field experiments (Tashkent, 2007)

7. M. Shodmanov, Bulletin of Agricultural Sciences 3(13), 44-46 (2003)

8. R. A. Kulmatov, S. A. Adilov, S. Khasanov, In IOP Conference Series: Earth and Environmental Science 614(1), 012149 (2020)

9. V. M. Zhidkov, I. V. Krivtsov, Protection and Quarantine of Plants 6, 28 (2003)

10. S. Isaev, I. Begmatov, G. Goziev, S. Khasanov, In IOP Conference Series: Materials Science and Engineering 883(1), 012080 (2020)

11. S. K. Isaev, R. U. Rakhmonov, S. S. Tadjiev, G. I. Goziev, S. Z. Khasanov, In IOP Conference Series: Earth and Environmental Science 614(1), 012147 (2020) 